\title{
Postmodern Feminism: Cultural Trauma in Construction of Female Identities in Virginia Woolf's The Waves
}

Leila Baradaran Jamili ${ }^{1 *}$, Ziba Roshanzamir ${ }^{2}$

${ }^{1}$ Assistant Professor of English Language and Literature, Faculty of Postgraduate Department of English Language and Literature, Boroujerd, Islamic Azad University, Boroujerd Branch, Iran,

${ }^{2}$ MA Student of English Language and Literature, Boroujerd, Islamic Azad University, Boroujerd Branch, Iran

Corresponding Author: Leila Baradaran Jamili, E-mail: 1bjamili@yahoo.com

\section{ARTICLE INFO}

Article history

Received: June 14, 2017

Accepted: August 03, 2017

Published: August 31, 2017

Volume: 8 Issue: 4

Advance access: August 2017

Conflicts of interest: None

Funding: None

\section{Key words:}

Gender,

Patriarchy,

Reconstruction of Identity,

Sexual Difference,

Trauma

\begin{abstract}
The present article sheds new light on trauma as a devastating phenomenon respecting the construction of male and female characters' identities and reveals reconstruction of male and female identities in Virginia Woolf's (1882-1941) The Waves (1931). Trauma is defined as an unexpected event that leaves the most terrible marks on the person's self, identity, psyche, emotions, beliefs, etc. Individual trauma is diagnosed by the male and female characters' horrendous responses regarded as post-traumatic stress disorder in terms of a distressing recollection of the traumatic occurrence. In contrast, cultural trauma, like patriarchy, gender, or sexual difference which has a horrific influence on cultures, can encompass traumatically the collective identity of male and female characters. In The Waves, the characters such as Rhoda, Jinny, and Susan get involved in the struggle for the self-definition relating to their collective and individual identities, respectively. No wonder, this article exploits an integrated method of feminism and psycho-trauma. It contextualizes the ideologies of postmodern feminist critics, such as Judith Butler (1956-), Helene Cixous (1937-), Cathy Caruth (1955-), and Luce Irigaray (1930-). Woolf, de facto, reveals how trauma as a catastrophe, either individual or collective, affects shockingly male and female characters' identities, so that their physical and psychological responses can be analyzed in terms of diagnosis of the trauma and its aftermath.
\end{abstract}

\section{INTRODUCTION}

The cultural trauma is one of the specific concepts of trauma related to collective memory identity, and to negative changes which may leave in its wake on the societal groups of the society. Human beings are in search of security, order, connection, certainty, meaning, identity, and love. If something unexpectedly occurs that severely undermines those necessities, surprisingly, those people are being traumatized as a result of traumatic occurrence. Therefore, trauma distorts the power, common sense, and understanding of the traumatized person. If an event traumatizes not only one individual but also all the members of a collectivity or a group, the trauma will be cultural trauma or collective trauma. Gender is different from sex. For many people, however, these terms are used incorrectly and astonishingly interchangeably. At birth, it is to assign sex by the use of physical attributes. But gender signifies socially constructed roles based on biological sex. Indeed, it can refer to the cultural expression of the sexed body. In this sense, the significance of gender is due to both social and cultural roles assigned to a person. Gender identity is characterized by the public expression of the gender role.
In The Waves $(W)$, Virginia Woolf indicates cultural or collective trauma linked with patriarchal society and gender roles that dominate females and their identities. It also challenges male identity and masculinity which create false hegemonic traits for males. This research uses viewpoints of Helene Cixous, Luce Irigaray, and Judith Butler to clarify the researchers' claim, as well as, it paves the way for trauma critics like Cathy Caruth and other cultural trauma theorists whose ideas can be hopefully helpful at best. Indeed, identity theorists' ideas are considered by the researchers.

\section{MATERIALS AND METHOD}

The present article aims at showing cultural trauma and its effects on forming identity. In order to do that the feminist critics, like Judith Butler (1956-), Helene Cixous (1937-), and Luce Irigaray (1930-) as well as literary trauma theorist, Cathy Caruth (1955-), have been selected. Butler discusses that gender is constituted through behavior in which gendered characteristics and dispositions are displayed. She believes that gender is not an underlying nature of which gendered behavior is produced; it is rather a series of acts that through repetition create the illusion that the underlying na- 
ture comes to existence. Butler challenges the performative trait of gender and also the relation of gender and identity in her book Gender Trouble: Feminism and the Subversion of Identity (1999):

[i]n other words, acts, gestures, and desire produce the effect of an internal core or substance, but produce this on the surface of the body, that suggest, the organizing principle of identity as a cause. Such acts, gestures, enactments, generally constructed, are perfomative in the sense that the essence of identity that they otherwise purport to express are fabrications manufactured and sustained through corporeal signs and other means. That the gendered body is performative suggests that it has no ontological status apart from the various acts which constitute its reality. (185)

Butler believes that gender is constructed through acts, traits, behavior affected by the internal essence and is exhibited by the body that is the cause of principles of one's identity. Because gender is itself performatively constituted, those principles of one's identity are not made in real domain by actual principles and only convey corporeal signs based on gender performativity. Such fabrications of identity are mostly concerned in this research. Thus, the gendered body that is performative does not have real position and is merely the subject of fabricated reality created within the cultural and social context; therefore, one's identity is constructed in this way is regarded as gender identity.

Further, Butler believes that feminists turn to patriarchal culture and develop it by dealing with the concept of gender built inevitably as masculine and feminine by constituting the naturalization of this historical notion. In this case, she asserts that, "[ $\mathrm{t}]$ he very notion of patriarchy has threatened to become a universalizing concept that overrides or reduces distinct articulations of gender asymmetry in different cultural context" (ibid 48). In her view, feminists reinforce the idea that patriarchy as a universal concept establishes gender notions regarding identity and emphasizes a norm or the fact of being biologically male or female in various cultural context.

More broadly, Cixous has collaborated with a group of poststructuralist feminist theorists who have been impressed by the work of Jacques Lacan (1901-1981) and Jacques Derrida (1930-2004). Surprisingly enough, Cixous practices and develops a mode of thinking "feminine mode" or Écriture féminine, referring to a path toward a sort of thought through the body. Being clearly indebted to a deconstructive critique of Western metaphysics as a system of oppositions, Cixous challenges the oppressive and gendered system in which femininity does not have any room or position. Instead, logic captures and imprisons the female. In order to provide the possible escape from subordination of the traditional and patriarchal structures as well as to examine exclusions from the oppressive structures, Cixous embarks a direct attack on the myths of femininity that have encompassed western culture:

Where is she

Activity/Passivity

Sun/Moon

Culture/Nature

\section{Day/Night \\ Father/Mother}

Head/Heart

Intelligible/Palpable

Logos/Pathos. [...]

Thought has always worked Through opposition,

Speaking/writing

Parole/Écriture

High/Low $[\ldots]$

Traditionally, the question of sexual difference is treated by coupling it with opposition: activity, passivity and all these pairs of oppositions are couple. [...]. Male privilege, shown in the opposition between activity and passivity, which he uses to sustain himself. (1986: 63-64)

Cixous argues that these hierarchical oppositions undermine feminine place and associate men with activity or with the former half or the superior side of these dichotomies. Irigaray challenges the sexual difference as well as Freudian views regarding female sexuality. She concludes that, based on Sigmund Freud's (1856-1939) theorization of sexuality, "[t]he feminine is always described in terms of deficiency or atrophy, as the other side of the sex that alone holds a monopoly on value: the male sex" (1985a: 69). Concerning such an idea, the feminine sexuality or sex is ascribed to lack of value; on the contrary, the male sex is characterized with value and domination. Exactly enough, the above stated view is criticized elaborately by Irigaray.

Cathy Caruth has established her place among academicians mainly by dealing with trauma studies as well as with literature, literary theory, and psychoanalysis. Caruth gives the definition of trauma in this way: "[ $\mathrm{t}]$ rauma, that is, does not simply serve as record of the past but precisely registers the force of an experience that is not yet fully owned" (1995: 150). Based on such a view, trauma is not only an event occurred sometime in the past but also is a traumatic experience which is not understood to the full. Caruth has been in an attempt to demonstrate the fact that trauma as an overwhelming phenomenon "is not a simple memory" (ibid). The trauma that leads to symptoms and diagnosis is known as post-traumatic stress disorder or official characteristics that were revealed by the American Psychiatric Association in 1980, "which included the symptoms of what had previously been shell-shock, combat stress, delayed stress syndrome, and traumatic neurosis, and referred to responses to both human and natural catastrophes" (ibid 20). The definition post-traumatic stress disorder refers to symptoms of those traumatic events such as shell shock, which can be experienced by a solider or a veteran in the combat field, or the traumatic neurosis, resulting from natural events like flood, earthquakes or human disasters such as car accident or plane crash and so on. Caruth believes that, "[t]he trauma is the confrontation with an event that, in its unexpectedness or horror, cannot be placed within the schemes of prior knowledge and thus continually returns, in its exactness, at a later time" (ibid 153). In her view, trauma is an abrupt and unforeseen phenomenon which is not digested due to its unknown essence. Afterwards, it is frequently taken place in the traumatized unconsciousness, and 
trauma may be both physical and psychological or it might be simply psychological.

\section{RESULTS AND DISCUSSION}

Cultural trauma is the sort of trauma affects culture, that is, "cultural trauma in the culturally interpreted wound to cultural tissue itself" (Sztompka 458). Based on such an idea, cultural trauma originates from traumatic events which aim at cultural bases in the society. It is a major factor in creating and making the collective feeling of being distressed. It is believed that cultural trauma is a big thread because like all cultural phenomena it is the most powerful inertia; moreover, it and its aftermath continue longer than any sorts of trauma. Sometimes either it is deeply embedded in several generations' beliefs, or it is kept in collective memory, or occasionally achieved salience when conductive conditions are provided. The appropriate instances of cultural trauma are known as tribal, ethnic, racial, and national traumas which appear violently and collapse powerfully and psychologically traumatized people. In the case of cultural process, "trauma is mediated through various forms of representation and linked to the reformation of collective identity and the remarking of collective memory" (Eyerman 1). According to what Ron Eyerman says, trauma in its cultural form is associated with the change occurred in collective identity and effects strongly collective memory. In this light, Caruth writes, "The traumatized, we might say, carry an impossible history within them, or they become themselves the symptom of a history they cannot entirely possess." (1995: 23). It is clear that the traumatized ma by cultural trauma carry a false meaning and truth rooted in a history, and they cannot fully understand and realize it. She goes further and claims that, " $[\mathrm{t}]$ he problem arises, not knowing how to establish the reality of their hallucinations and dreams; it occurs within the very knowledge and experience of the traumatized themselves" (ibid 25).

According to Caruth, those who are traumatized cannot cope with the reality of their painful responses to trauma; instead, they consider only their traumatic experiences and resist against the associative chains of meaning relating to their trauma. By cultural trauma the members of a collective traumatized cannot realize the traumatizing disasters shattering their collective sense and they see the life through the lens of culturally embedded false current beliefs and changes.

Patriarchal system describes a system or an organization in which males hold power and play roles as the head and leader of the family. Patriarchy is "[a] system ruled over by men, whose authority is enforced through social, political, economic and religious institution" (Gamble 271). It is understood that patriarchy is a systematic organization in which men's domination is represented by different kinds of insinuations. Postmodern feminist theorists draw on psychoanalysis and poststructuralist concepts in order to indicate patriarchy as an ideology penetrating into every aspect of culture like language. Deborah L. Madsen has pointed out that "[p]atriarchy is a cultural system that privileges men and all things masculine, and a political system that replaces power in the hands of men and thus serves male interests at the expense of women" (xii). Culture contributes to patriarchy and consequently cultural trauma respecting patriarchy is created. Because its negative outcome permeates collective memory, and identity positions hegemonic masculinity defined based on patriarchal order in terms of cultural crisis. In this sense, patriarchy does not need to be felt by all the members in a community.

Relating to patriarchy, Ann Oakley, in her book Sex, Gender and Society (1985), believes that, "gender roles and gender identities are not acquired mechanically by the child from the parent, but because the child identifies with the parent in a variety of ways" (179). It seems that the child is motivated to be like the parent and puts herself or himself in the same gender classification as the parent. In this case, "sex differences may be natural, but gender differences have their source in culture, not nature" (ibid 189). These beliefs regarding the differences of sex and gender and that the former is by birth and the latter has been culturally running throughout the centuries and more or less the debate is renewed; however, the same sentiments are recognized as reasons for feminists who concentrate on the system of sex-gender difference.

\section{Postmodern Feminism: Gender, or Sexual Difference}

The postmodern feminism is known by theorists like Luce Irigaray, Helene Cixous, and Judith Butler who have followed the ways in which sexual difference is shaped by language and culture. They challenged Jacques Lacan's psychoanalytic concepts including 'Symbolic Order.' They try to deploy a female identity, language, and related writing which are able to deconstruct or subvert the superiority of the male discourse of that Symbolic Order.

Judith Butler is the feminist and literary theorist who has elaborated on the theory of gender performativity which has been taken up in her book Gender trouble in 1999. In this book, she concentrates on the notions of gender, sex, gender identity, and gender performativity. Butler believes that if the 'body' is perceived based on its sexed signification, "[t]his body often appears to be a passive medium that is signified by an inscription from a cultural source figured as 'external' to that body" (1999: 175). She regards body as an external passive tool characterized by cultural factors. Regarding the performativity of gender, she points out: "gender, for instance, as a corporeal style, an 'act', as it were, [...] is both intentional and performative, where 'performative' suggests a dramatic and contingent construction of meaning" (ibid 190). In her opinion, gender is constructed based on those dramatic acts, giving meaning to gender as a performative medium. Meanwhile, according to Butler, "there is neither an 'essence' that gender expresses nor an objective ideal to which gender aspires, the various acts of gender create the idea of gender, and without those acts, there would be no gender at all" (ibid). Concerning her theory, gender is not fact, it does not contain objective ideal and without those acts which form gender structure it cannot exist by itself.

Irigarary says that women "are outsiders where cultural values are concerned they are deprived of the worth of their 
sex" (1985a: 71). That is, women are not defined based on cultural values of the society because they are considered worthless due to their sex. In her book This Sex Which Is Not One (1985), she challenges Freud's definitive structure of femininity as passive and masculinity as active. In addition to this, she re-considers Freud's Oedipal complex, and opposes Lacan's Symbolic Order through which women's inequality and discrimination in employment and education are established. In short, patriarchy established through that Symbolic Order is challenged by Irigarary. She demonstrates women as independent beings who have sexual specific identity repressed by phallocentric subjectivity. Irigarary asserts that, "women's exploitation is based on sexual difference, [hence;] its solution will come only through sexual difference" (1993: 12). Irigaray comes to believe that sexual difference is the factor of women's slavery and this problem is solved merely by itself. In this regard, she adds that, "[i]t is vital that a culture of the sexual, as yet nonexistent be elaborated, with each sex being respected" (ibid). She stresses that if each sex is respectfully and culturally considered this problem will be solved.

Helene Cixous is a prominent figure or the mother of the post-structural feminist theory. One of her most significant achievements was her contribution to a post-structural analysis of difference which first was kept at the core of Saussurean linguistic theory which denotes that binary oppositions are essential forms of producing meaning like day/night or black/white. Difference can have a negative construction like exclusion or marginalization relating to those who are ascribed to being defined as 'other' or as outsiders. Cixous devaluates binary oppositions and focuses on gender divisions due to those oppositions, and also she discusses that the dichotomy of culture/nature, defended by structuralist, Lévi-Strauss (1908-2009), is attributed to the dualism of men/women.

In fact, Cixous looks for establishing a feminine identity in social and cultural norms by fighting against representing gender in quality which has been the consequence of being caught by Phallocentric logic and culture. She asserts, "[b] ut we must make no mistake: men and women are caught up in a web of age-old cultural determinations that are almost unanalyzeable in their complexity" (1986: 83). Cixous reveals that both men and women are defined based on cultural determinations which are too complicated to be analyzed. In Woolf's The Waves, Irigarary, Cixous, and Butler's ideas and notions about the construction of male and female identities are examined by having an eye on cultural trauma.

\section{Patriarchy and Gender: Construction of Female Identities in The Waves}

Woolf, in The Diary of Virginia Woolf $(D)$, puts The Waves, "into a series of dramatic soliloquies, in the rhythm of the waves" (D3: 312). In fact, she makes a situation in which the characters enter into "the privacy and self-analysis of the speeches" (Snaith 82). And they start defining themselves as if they ride on waves and surf through them. In other words, the characters reveal their privacy and themselves by their speeches or through soliloquies.
In the novel, three females, Rhoda, Jinny, and Susan who are traumatized in terms of their selves and the construction of their individual and collective identities are traumatized. Rhoda's suicide and the feeling of her nothingness, non-being, and annihilation, Jinny's act of showing off and her behaving against current norms of patriarchal or male-centered society, and Susan's ambivalent emotions, the feeling of love and hatred, as well as her being imprisoned or captured in patriarchal culture are discussed. Throughout the novel the construction of their identities collectively is traumatized based on some cultural traumas, including patriarchy and gender inequality. The sense of their well-being and the notion of who they are or we-ness are shattered and hurt by cultural traumas mentioned above.

The male and female characters are in quest of the reconstruction of their own traumatized identities. Woolf, by revising her individual and cultural traumas in her fictional and non-fictional works, tries to alleviate and heal her traumatized identity. The Waves, as Woolf confesses, is autobiographical novel. Woolf's novel is preoccupied with her personal, painful, and traumatic experiences. For instance, her half-brother's sexual violations cause her show some responses as post-traumatic stress disorders, so that she is ashamed of looking at her own face in the glass. In The Waves, she describes it through Rhoda to recover or recuperate her own shattered identity and Rhoda's traumatized self and identity. Despite the fact that Woolf alleviates Rhoda's suffering and traumatized identity completely differently, that is, by death.

\section{Cultural trauma: Rhoda and nothingness or facelessness}

Rhoda, as one of the female characters through some soliloquies, tries to indicate her self and identity. However, she is different from two other female characters, Jinny and Susan. In the opening section of the story, Rhoda defines herself in this way: "Alone, I often fall down into nothingness. I must push my foot stealthily lest I should fall off the edge of the world into nothingness. I have to bang my head against some heard door to call my self back to the body" ( $W 12)$. Rhoda is unable to identify her identity, and sees herself into nothingness. As a matter of fact, she is repressed in the extreme. According to Cixous, in binary oppositions of Western culture and philosophy woman's position is subject to phallocentric guarantee. Then, woman is unprivileged and is dependent on men; as well as, she is considered as an outsider in that hierarchical oppositions. In this regard, Cixous asserts, "[e]ither woman is passive or she does not exist. What is left for her is unthinkable, unthought" (1986: 64). Cixous explains that, in this system, woman is ignored as if she does not exist.

Similarly, Rhoda who "falls down into nothingness" is associated with this passivity of the culture and has to sustain herself by attaching to her body ( $W 12$ ). Nevertheless, in the story it is shown that she cannot do this and is doomed to death. Because of understanding her position relating to nothingness, she is unable to concentrate. Furthermore, Rhoda's self and identity are affected by this nothingness and work in complete isolation. As Maria DiBattista claims: "[t]he true self can only be experienced or captured or known when it 
is set free to imagine what it might be like to be, in no particular order" (32-3). Based on her idea, a normal self is not concerned with any especial hierarchical system or order. Rhoda's self and identity act in the opposite direction of the actual identity because of that imposed and dual organization. It is believed that "[c]lass difference, racial diversity, the multiplicities of sexual orientation and gender identity have been made the bases of different kinds of identity politics" (Spencer 9). Identity legacy works based on sexual, gendered, racial, and class differences. As Woolf shows it often in most of her works and reveals that the construction of her female characters' identities is impressed by those above issues. She starts “questing sexual identity to criticize society's differential treatment of men and women as a challenge" (Gay 160). As a matter of fact, she challenges sexual identity through showing society's confrontation with sexual difference.

In the second section, when the characters are at the school, Rhoda feels nervous and declares: "[b]ut here I am no body. I have no face I will seek out a face, and will endow it with omniscience" ( $W$ 22). Rhoda defines herself as faceless, but she desires an ideal face for herself. Throughout the novel, Rhoda refers to her facelessness several times, "[b]ut there is no single scent, no single body for me to follow. And I have no face" ( $W$ 23). It seems that Woolf, deliberately, puts faceless Rhoda in the story. In Western culture or metaphysics, according to Cixous, "woman is always associated with passivity in philosophy. She has not been able to live in her 'own' Louse, her own body. Their bodies, which they haven't dured enjoy, have been colonized" (1976: 66-67). Cixous criticizes exclusion of women from their bodies due to their passivity. She comes to conclusion that women are separated from their bodies because their bodies are colonized.

In fact, Cixous challenges "a series of binaries such as man/woman, nature/culture, mind/body [which] will work to assert the first time as the property of truth or logos and the second time as defective copy of the first, as incomplete" (Bray 25). It is realized that in the binaries the second term is subject to the first one and is unprivileged in comparison to the first one. Accordingly, Iraj Montashery believes, "Woolf in this novel questions binary thinking severely because it is reductive and restrictive" (808). That is to say, through the novel, Woolf challenges binary oppositions in view of their destructive results. By Rhoda's being faceless, Woolf puts emphasis on the binary dichotomies, and on women's identities, as colonized and invaded like Rhoda's. Effacing women in oppositions as a way is "'to think of identity as something which only comes into being through unacknowledged debt to difference" (Bray 24). Identity or female identities are linked to differences in binary oppositions. Likewise, Rhoda's identity is defined through "culturally-determined features" (Davis 168). Those features established based on these oppositions have created cultural trauma for women.

Neil Smelser asserts: "[t]hat cultural traumas are for the most past historically made, not born. This fundamental point leads to the mechanisms and agencies involved in the process of making, to which we will turn presently" (37). Indeed, cultural trauma is made based on the past history, and in the process of making cultural trauma the agencies and mechanisms are engaged. By the same token, the oppositions are historically made by Western culture as agencies and mechanisms are to create cultural trauma.

In the seventh section, "Rhoda's love of dream starts to the love of death" (Randhir Praptap 90). Because Rhoda lives in an unreal life by her imagination, she comes to believe in death: "[n]ow I climb this Spanish hill; and I will suppose that this mule-back is my bed and I lie dying. There is only a thin sheet between me now and the infinite depths" ( $W$ 180). Rhoda seeks a shelter in which she lies dying and gets calm by relinquishing a thin sheet that is her preventive and corporeal body. Cixous points out, "many women wonder whether they even exist. They feel they don't exist and wonder if there has ever been a place for them" (1981: 43). Cixous highlights that woman has no place as if she does not exit at all. She represents woman's position in the male-centered society. Accordingly, Rhoda has no place and wonders if there has ever been a place for her. Thus, she is not able to find out answers and say welcome to death. In the dairy entry, in 1935, Woolf notes that she met E. M. Forster in London Library and the conversation which have taken place between them clarifies Woolf's feelings toward women's place in the male-centered society:

I met Morgan [E. M. Forster] in the London Library yesterday \& flew into a passion. "And Virginia, you know I'm on the co [mmi] ttee here" Said. Morgan. "And we've been discussing whether to allow ladies- I was then to refuse: oh but they do- I said. "No, ladies are quite impossible. See how my hand trembles. I was so angry (also very tired) standing. And I saw the whole slate smeared. I thought now perhaps M. [Forster] had mentioned my name \& and they had said no no no: Ladies are impossible. (D4: 297-8)

Woolf tells the memory regarding Forster's assaulting discussions about women that "ladies are quite impossible" and she becomes so annoyed at his offensive expressions concerning ladies and she opposes him severely. Woolf wants women to get their appropriate places and the rooms of their own. She cannot tolerate that women are assigned in the lowest position of the society.

Woolf, in her essay "Professions For Women," in The Death of the Moth and Other Essays (DM) considers women as self-scarifying creatures who are completely devoted their life or themselves to the family either to their parents or to their husbands, like 'The Angle in the House': "[s] he was intensely sympathetic. She was utterly unselfish. She excelled in the difficult arts of family life. She sacrificed herself daily" (DM 172). The sort of woman portrayed by Woolf is the self or sacrificial one who does not have a definite depiction of herself and her life is merely devoted to her family and to male community. In conclusion, Woolf decides to kill her traditional self and create a new one: "[k]illing the Angle in the House was part of the occupation of a woman writer. The Angle was dead what remained was a simple and common object-a young woman in a bedroom with an inkpot" (DM 173). No wonder, Woolf wants to draw society's attention to women's ignored place to restore their sexed and gendered identities to their real identities; it means identities with or without bias of sex and gender. 
Woolf, in fact, kills Rhoda as an 'Angle in the House' who has no face and falls into nothingness, hoping that female identity, traumatized culturally by oppressions of patriarchal society, can get her real sense of well-being: "[ $\mathrm{t}] \mathrm{he}$ Angle censors [...] related to the woman writer's physical, including sexual, identity - the elements of her life that are most different from a man's" (Black 57). Woolf highlights the differences between women's life and men's constructed ones based on women's sexual identity. Irigarary supports Woolf's phantom, 'Angle in The House', like this: "[ $t]$ hey have sacrificed their own identity as women or that of their sisters in order to conform, or make their sisters conform, to a socio-historical conditioning that is man's" (2000: 34). Based on Irigarary's view, women sacrifice themselves in view of historically and socially embedded traumatic patriarchal culture.

\section{Jinny's traumatized identity: A fake truth beyond sex or corporeality}

Surprisingly, in The Waves, Woolf puts a female character Jinny to be considered in accordance with her sexual identity. Jinny's sexual identity has been described as a part of her identity that threatens "[her] positive self-evaluation" and "[her] cognitive response" to "have a reasonably high self-esteem" (Simon 33). Jinny, in fact, lives with her sexual identity. However, it is the main factor of decreasing her self-concept and self-esteem. In the sixth section, Jinny who is now in her thirty says: "[b]ut we who live in the body see with the body's imagination things in outline. For now my body, my companion, which is always sending its signals" ( $W$ 167). Jinny lives with her body and sees anything through its lens. By this, Woolf draws attention to sexual female body that, "allows truth to appear underneath the mask and fakes, shadows, are already artificially fabricated, mimed" (Irigarary 1985a: 266). In Irigarary's view, sexual female body is a mask which hides truth. Correspondingly, Woolf demonstrates Irigarary's idea by Jinny displaying a fake truth through her body and her sexual identity as a fabricated mask for her real identity. Naomi Black classifies Woolf's feminism "among the social feminists, because of her valorization of women's 'civilization' as a basis for social and political transformation" (10). She labels Woolf as a social feminist focusing on women's social and political changes. Thus, Jinny who only lives with her body and corporeality is culturally wounded and traumatized.

Because, as Caruth says, "[i]n trauma, [.], the outside has gone inside without any meditation" (1996: 59). According to Caruth, trauma is embedded unmediatedly. Likewise, Jinny's display of her sexual identity is ingrained in her inside without any thought since during the history women have been taught to think only based on their sexual identities. And this shatters their beliefs regarding their collective identity and consequently, the cultural trauma occurs to them. From Woolf's perspective, "over it all is some odd pale unnatural atmosphere. No normal life. I think we shall become more independent \& social as the days go on" (D3: 78). Based on Woolf's view, women have no normal and natural life and they should become more social and independent.
This view designates Black's idea respecting Woolf's social feminism.

Clearly, Woolf as a woman is concerned with female concerns within the limits of the society where false and fake beliefs about females have been made into models molded by society morns. By Jinny, in the novel, Woolf tends to reveal that how or to what extent the society would be wrong to give priority to "a discussion of gender identity for the simple reason that "persons" only become intelligible through becoming gendered in "conformity with recognizable standards of gender indelibility”. (Butler 1999: 59). Concerning what Butler said the society standards or the current cultural terms of the society contribute to leading convections to constitute gender identity to be related to the definition of the structure of becoming gendered.

In the noved, Jinny says, "my imagination is the body's. [...]. Men, how many have broken from the wall and come to me. I have only to hold my hand up. Straight as a dart they have come to the place of assignation." (W 161-2) Jinny only focuses on her body and likes to draw men's attention. She thinks highly of her body. It is because the society establishes the identity as an effect of gender identity. The society categorizes sex, gender, sexual identity, and gender identity through regulatory practices in a masculinized society. Infact, the fake representation of women based on their sexual and genederd identity is constituted through the field of power articulated in the patriarchal society.

Jinny is a character traumatized by being attached to her body and to "the artificial [...] means by which [...], order, and identity are effectively instituted." (Butler 1999: 65) Jinny's identity is constructed through some unreal notions. As a matter of fact, Woolf attempts to make use of the fictitious character like Jinny, in her novel, to appear under-representation in the ways which they can address the gendered identity of the females and its reflection in a patriarchal society. Jinny in the second part of the novel refers to the fact that she lives with throughout her life, "[M]y body lives a life of its won. [...]. I open my body, I shut my body at my will. Life is beginning. I now break into my hoard of life" (W 445). Jinny repeats the word of "body" again and again in the novel. But by these sentences, it is understood that she as a suppressed woman is growing through gender regulations or false beliefs regarding women's gendered identity and personal identity.

\section{Susan's traumatic identity: Patriarchal culture}

Susan is chained by her gender roles in the world of patriarchy made by her father and husband. Through Susan, "[t] o Woolf, it was still important to fight patriarchy" (Kathmann 7). In fact, Woolf wants to depict the patriarchal power with which she fought during her life. In the novel, Susan is subject to her father and reminds readers frequently of this dependence: "[ $t]$ his is my first night at school away from my father, away from my home. My eyes swell; my eyes prick with tears" ( $W 19)$. In retrospect, Susan hates being at school due to being far away from her father. Thus, she feels extremely upset. Clearly, Woolf, through her fictional and non-fictional works, challenges "[V]ictorian patriarchal cul- 
ture, and the whole weight of that culture" (Dalsimer 29). It shows, according to Woolf, patriarchy roots in the culture especially in Victorian culture; consequently, cultural trauma, resulting from this hegemonic destructive culture, affects the construction of female identities or their collective identities. Butler names patriarchy as "the universal or hegemonic structure or masculine domination" (1999: 5) Regarding Butler's view, patriarchy is understood as a dominant, global, and masculine notion.

Woolf questions this hegemonic culture in one of her book-length essays, Three Guineas (TG). However, Woolfian scholar, Naomi Black, believes, that it is "combination of fiction and non fiction" (16), that is to say, it is both fictional and documentary. The book is based on letters and answers to them and is considered as a long letter. Peace, not war, is the central subject of the book; in Woolf's view, the cause of war is centered on the oppression and tyranny that done toward women. To end the systems of tyranny and oppression personified as men, such as Fascism, Nazism, and world political armed power like war, it is necessary to put an end to what happens in families, including " $[\mathrm{t}]$ he furthest extensions of patriarchal power, hierarchical structures of society that constrain, psychologically deform, and often kill both women and men" (TG 17). With respect to the above sentences, if patriarchal power and hierarchical orders are destroyed in the families, the political, civil, and international wars embodied in men will be able to be dismissed because both women and men are hurt and traumatized by these destructive patterns.

Furthermore, the suppression imposed on women is much through educational, political, and economical organizations. Also, she challenges women's dependence on men, especially in terms of financial issues, and she traces social and fundamental reforms for women in the case of their marriage regarded as a trade and profession for women at that time: "[father] wished to keep his daughter in his power. If she took it from another man not only was she becoming independent of, she was becoming dependent upon another man" (ibid 83). Woolf has a critical eye on fathers' superiority that they have over their daughters to get them dependent on themselves more financially. She questions patriarchal system in a letter to Leonard Woolf in 1912, " $[\mathrm{t}]$ hen I say By God, I will not look upon marriage as a profession. I want everything - love, children, adventure, intimacy, work" (L1: 496). She desires more important things like love, family, and profession than being supported by her husband through marriage as a business. Therefore, Woolf "speaks of women becoming "class-conscious" (Whitworth 152). She classifies women as an exclusive group. Susan was forced into strict roles to perform the domestic roles relating to that of wife or mother.

Her gender identity is constructed by a series of special gender roles and practices: "[b]ut who am I. I shall have children. I shell be like my mother; silent in a blue apron locking up the cupboards" ( $W$ 52). Susan challenges herself and finds out that she is like her mother who devoted herself to her family. Regarding gender performativity which exposes artificial and compulsory attributes as well as a parody of normative gender, Butler argues: "[g]ender ought not to be constructed as a stable identity; rather, gender is an identity tenuously constituted in time, instituted in an exterior space through a stylized repetition of acts" (1999: 191). Butler insists on this subject that gender should not be considered as a "stable identity," but it is constructed and formed by a series of repetitive and fashionable acts during the time.

Connecting Butler's ideas with Susan's constructed gender identity by a repetition of acts can adjust Susan's stable gender identity dictated to her to act in a repetitious way as her mother did. Susan only adheres to the illusionary gender identity and performativity that society normalizes it for female identities and makes women silent by defining domestic tasks for them. This shows that "a constructed identity, a performative accomplishment which the mundane social audience, including the actors themselves, come to believe and to perform in the mode of belief" (ibid 192). Butler believes that social actors (like women) perform in an ordinary way which reinforces their belief in themselves as only dictated performers. Similarly, Susan performs her gender roles in a mundane way and imitates only the tasks defined as regular notions for female communities.

As a result, "[c]ultural trauma occurs when members of a collectivity feel they have been subjected to a horrendous event that leaves indelible marks upon their group consciousness, changing their future identity in fundamental and irrevocable ways" (Alexander 2004: 1). Indeed, cultural trauma as a terrible and horrific event that can mark consciousness and identities of the members of a collective traumatized can make their collective identities change basically. Then, cultural trauma of gender performativity, illusionary, and artificiality makes identities traumatized "in which its precise images and enactments are not fully understood" (Caruth 2009: 153). In fact, traumatized members cannot completely realize the specific and accurate nature and essence of their trauma. They merely get involved in this trauma unknowingly by a series of historically defined repetitive acts regarding their gender identities. Thus, their construction of identities is affected by these cultural traumas and as a result of this they are traumatized.

\section{CONCLUSION}

The construction of male and female identities is traumatized because of cultural traumas that during the history shatter people's sense of belonging. Cultural traumas such as patriarchy and gender leave collective members in a destructive chain of cultural decay and destruction. Cultural trauma is defined as cultural shock that aims at cultural tissue of society creating typical conditions under which cultural trauma emerges and evolves. The cultural trauma along with its traumatic symptoms, including false belief in specific behavioral patterns, exclude, a community (like women) from active normative valuable social contexts. In addition, when cultural traumas occur, human identities lose their coherence, stability, and foundations. In fact, they become culturally traumatized and cannot connect themselves to social and cultural context and valuable core of collectivity. 
Patriarchy, gendered and sexed identity are, for instance, cultural traumas which act as destructive components, corrupting more precisely bases of identity and foundations of collective sense of well-being. Besides, collective pride is corrupted by these kinds of cultural traumas. A wrong belief in controlling female community by patriarchal structure wounds female's class consciousness and their substantive identities that can lead to false direction or cultural trauma. Correspondingly, gender binary system and wrong interpretation of its definition gives birth to collective trauma impressing collective identity or a shared sense of being. Contemporary feminists, such as Butler, Irigarary, and Helene Cixous, focusing on women's exclusion from masculine world, are in the attempt of including women in this world as valuable creatures by having fair equality in cultural and social context.

Thus, in this article, Caruth and other cultural trauma theorists and thinkers contribute to these feminists in order to accomplish researchers' goal in examining Woolf's The Waves through the lens of the effects of patriarchy and gender as the cultural trauma on construction of male and female identities of the novel. Notwithstanding the fact that males of the story are trapped in these cultural traumas like patriarchy and gender notions and appear to be traumatized by them.

\section{REFERENCES}

Alexander, Jeffrey C (ed). Cultural Trauma and Collective Identity. London: California UP, 2004.

Black, Naomi. Virginia Woolf as Feminist. New York: Cornell UP, 2004.

Bray, Abigail. Helene Cixous: Writing and Sexual Difference. New York: Palgrave Macmillian, 2004.

Butler, Judith. Gender Trouble: Feminism and the Subversion of Identity. New York: Routledge, 1999.

Undoing Gender. New York: Routledge, 2004.

Caruth, Cathy. Empirical Truths and Critical Fictions: Locke, Wordsworth, Kant, Freud. Batimore: The Johns Hopkins UP, 2009.

Unclaimed Experience: Trauma, Narrative, and History. London: The Johns Hopkins UP, 1996.

Trauma: Explorations in Memory. Blatimore: The Johns Hopkins UP, 1995.

Cixous, Helene. "Casteration or Decapitations?". Sings. Transl. Annette. Kuhn. 7:1 (Autumn, 1981) 41-55.

The Newly Born Woman. Ed. Catherine Clement Minneapolis: Minnesota UP, 1986.

Cixous, Helene et al. "The Laugh of the Medusa." Signs, 1: 4. 875-893.

Dalsimer, Katherine. Virgina Woolf Becoming a Writer. New Haven: Yale UP, 2001
Davis, Robert Con. Hélène Cixous: Critical impressions. Eds. Jacobus A. Lee, and Regina Barreca. Amsterdam: Overseas publishers Association (OPA), 2005.

DiBattista, Maria. Imaging Virigina Woolf: An Experiment In Critical Biography. Oxford: Princeton UP, 2009.

Eyerman, Ron. Cultural trauma and Collective Identity. Ed. Jeffery C. Alexander. New York: Cambridge UP, 2003.

Gamble, Sarah (ed). The Routledge Companion to Feminism and Postfeminism. London: Routledge, 2001.

Gay, Jane. D. Virginia Woolf's Novels and the Literary Past. Edinburgh: Edinburgh UP, 2006.

Irigarary, Luce. Democracy Beings Between Two. Transl. Kirsteen Anderson. London: The Athlone, 2000.

This Sex Which is Not One. New York: Cornell UP, 1985a.

Toward a Culture of Difference. (je, tu, nous). Transl. Martin Alison. New York: Routledge, 1993.

Kathmann, Ute. "Virginia Woolf and the F word on the Difficulties of Defining Woolf's (Anti) Feminism." MA. Thesis in Literature/Culture/Media, Sweden. Lund U, LIVR07, Spring 2012.

Madsen, Deborah L. Feminist Theory and Literary Practice. London: Pluto, 2000.

Montashery, Iraj. "Rhoda's Non-Identity in Virginia Woolf's The Waves". Advances in Asian Social Science (AASS), 4:2 (2013) 806-808.

Oakley, Ann. Sex, Gender and Society. Aldershot: Gower/ Maurice Temple Smith, 1985.

Randhir Praptap, Singh, The Novels of Virginia Woolf. New Delhi: Sarup \& Sons, 2004.

Simon, Bernard. Identity in Modern Society A Social Psychological Perspective. Oxford: Blackwell, 2004.

Smelser, Neil et al. Cultural Trauma and Collective Identity. London: California UP, 2004.

Snaith, Anna. Virginia Woolf. Public and Private Negotiations. New York: Palgrave, 2000.

Spencer, Jane. Third Wave Feminism: A Critical Exploration. Eds. Stacy Gillis et al. London: Palgrave Macmillian, 2004.

Sztompka, Piotr. "Cultural Trauma: The Other Face of Social Change.” European Journal of Social Theory 3:4 (2000) 449-466.

Whitworth, Michael. Oxford World's Classics: Virginia Woolf. New York: Oxford UP, 2005.

Woolf, Virginia. The Dairy of Virginia Woolf. Vol.4: 19311935. Ed. Anne Olivier Bell. Florida: Harcourtp, 1982.

The Diary of Virginia Woolf. Vol.3: 1925-1930. Ed. Anne Olivier Bell. Florida: Harcourtp. 1980.

The Letters of Virginia Woolf. Vol.1: 1988-1912. Eds. Nigel Nicolson and Joanne Trautmann. New York: Harcourt Brace Joranovich P. 1975.

The Waves. Ed. Mark, Hussey. London: Harcourt P, 2006. 